\title{
A new Permian species of Mooreoceras (Cephalopoda: Orthocerida) from northwestern Peninsular Malaysia
}

\author{
By Shuji Niko, ${ }^{*), \dagger}$ Masatoshi Sone, ${ }^{* *)}$ and Mohd Shafeea LEMAN ${ }^{* * *)}$ \\ (Communicated by Tatsuro Matsumoto, M. J. A.)
}

\begin{abstract}
A new orthocerid cephalopod species, Mooreoceras sibumasuense sp. nov., is described from the lowest part of the Chuping Formation in Bukit Tungku Lembu of the Perlis State, northwestern Peninsular Malaysia. The holotype of the species occurs in argillaceous limestone that is most likely late Kungurian (late Early Permian) in age and was deposited under cool-temperate water conditions on the Sibumasu Terrane of the eastern Cimmerian Continent. Most Permian species of Mooreoceras appear to be palaeobiogeographically confined to cool to cool-temperate palaeoclimate zones of the Australian Gondwana to Sibumasu region. Mooreoceras sibumasuense sp. nov. belongs to a group that probably survived due to isolation from high predatory stress in tropical to temperate seas.
\end{abstract}

Key words: Chuping Formation; Mooreoceras sibumasuense sp. nov.; Orthocerida; late Early Permian; Peninsular Malaysia; Sibumasu Terrane.

Introduction. A single specimen representing a new species of the orthocerid cephalopod genus Mooreoceras was collected from Bukit Tungku Lembu of the Perlis State in northwestern Peninsular Malaysia (Fig. 1). The fossil locality is situated within the Sibumasu Terrane ${ }^{1)}$ of the eastern Cimmerian Continent. ${ }^{2)}$ Permian strata of the Perlis area are divided into the two main lithostratigraphic units; namely the siliciclastic Kubang Pasu Formation and the carbonate Chuping Formation in ascending order. ${ }^{3)}$ The lowest part of the Chuping Formation (up to 30 feet thick) consists of well-bedded limestone interbedded with chert, siltstone and sandstone. Jones $(1981)^{4)}$ defined this part as the passage beds between the two formations, in which the present cephalopod occurs. Ishii et al. (1972) ${ }^{5)}$ previously reported a brachiopod assemblage including Cancrinella cancrini (Vernuil) from the cephalopodbearing level at Bukit Tungku Lembu. They suggested a general Middle Permian age for the fauna. Jasin and Koay $(1990)^{6)}$ described the so-called anti-tropical fusulinids Monodiexodina shiptoni (Dunbar) and M. sutschani-

\footnotetext{
*) Faculty of Integrated Arts and Sciences, Hiroshima University, 1-7-1, Higashihiroshima, Hiroshima 739-8521, Japan.

**) Asia Centre and Earth Sciences, University of New England, Armidale, New South Wales 2351, Australia.

***) School of Environmental Sciences and Natural Resources, Universiti Kebangsaan Malaysia, 43600 Bangi, Selangor, Malaysia.

$\dagger$ Correspondence to: S. Niko.
}

ca (Dutkevitch) from a calcareous sandstone bed of the upper Kubang Pasu Formation at Bukit Wang Pisang. The age of this fusulinid bed was interpreted to be late Early Permian by Jasin and Koay $(1990)^{6)}$ and more specifically to be Kungurian by Ueno $(2003)^{7)}$ based on fusulinoid biozonation and a regional stratigraphic analysis. The Monodiexodina-bearing level is stratigraphically lower than the passage beds. Thus, it is here considered that the cephalopod-brachiopod horizon in the passage beds is most likely later Kungurian in age.

\section{Systematic paleontology}

Subclass Nautiloidea Agassiz, 1847 ${ }^{8)}$

Order Orthocerida Kuhn, 1940 ${ }^{9)}$

Superfamily Pseudorthoceratoidea Flower and Caster, $1935^{10)}$

Family Pseudorthocratidae Flower and Caster, $1935^{10)}$

Subfamily Pseudorthoceratinae Flower and Caster, $1935^{10)}$

Genus Mooreoceras Miller, Dunbar and Condra, $1933^{11)}$

Type species. Mooreoceras normale Miller, Dunbar and Condra, $1933 .^{11)}$

Mooreoceras sibumasuense sp. nov.

Figs. 2.1-2.6 




Fig. 1. Geologic map, modified from Jones $(1981){ }^{4)}$ showing the fossil locality (asterisk) at Bukit Tungku Lembu in the Perlis State, northwestern Peninsular Malaysia.

Diagnosis. Large species of Mooreoceras with approximately 1.2 in shell form proportion and smooth shell surface; ventral shell wall thickened attaining 1.8 $\mathrm{mm}$; sutures faintly oblique with approximately $5^{\circ}$ angle of rectangular plane to shell axis; siphuncular position proportion approximately 0.3 ; cameral and endosiphuncular deposits absent in adoral shell.

Description. Large-sized orthocone for genus with gradual shell expansion indicating its angle of approximately $4.5^{\circ}$ in dorsoventral plane; cross sections of shell are dorsoventrally depressed, oval, having shell form proportion (lateral diameter/dorsoventral diameter) approximately 1.2; adoral end of holotype (adoral portion of phragmocone) attains $24.6 \mathrm{~mm}$ in dorsoventral and $30.2 \mathrm{~mm}$ in lateral diameters; shell surface smooth, lacking distinct ornamentation; ventral shell wall is slightly thicker than dorsal one, attaining $1.8 \mathrm{~mm}$. Sutures faintly oblique, towards apex on dorsum with approximately $5^{\circ}$ in angle for rectangular plane to shell axis, weakly sinuate to form shallow ventral and dorsal lobes and lateral saddles; septal curvature moderate for genus; mural area of septa absent; camerae exceptionally short possibly representing gerontic nature, with width/length proportions ranging from 8.4 to 11.6. Siphuncle subcentral, shifting ventrally in position; siphuncular position proportion (distance of central axis of septal foramen from ventral shell surface per corresponding dorsoventral shell diameter) is approximately 0.3 ; septal necks suborthochoanitic in ventral siphuncular wall, and cyrtochoanitic in dorsal siphuncular wall; well-preserved dorsal septal neck at approximately $21 \mathrm{~mm}$ in dorsoventral shell diameter is $0.48 \mathrm{~mm}$ in length and $0.23 \mathrm{~mm}$ in brim width; connecting ring not preserved; cameral and endosiphuncular deposits absent in preserved adoral portion of holotype.

Material examined. The holotype, UMUT PM28964, is an incomplete phragmocone of approximately $87 \mathrm{~mm}$ in length. This specimen is reposited in the University Museum of the University of Tokyo.

Occurrence. Mooreoceras sibumasuense sp. nov. 



Fig. 2. 1-6. Mooreoceras sibumasuense sp. nov., holotype, UMUT PM28964. 1, lateral view, venter on left. 2, partial enlargement of Fig. 2.1, arrow indicates siphuncular position. $\mathbf{3}$, cross-sectional view of adoral end, venter doun. $\mathbf{4}$, dorsoventral thin section, showing internal structure, most apical camera is probably shortened by post morten deformation, venter on left. $\mathbf{5}$, partial enlargement of ventral siphuncular wall. 6, partial enlargement of dorsal siphuncular wall. 7. Photomicrograph showing lithology of matrix of $M$. sibumasuense. Scale bars represent $10 \mathrm{~mm}$ in Figs. 2.1, 2.3, $5 \mathrm{~mm}$ in Fig. 2.2, $1 \mathrm{~mm}$ in Fig. 2.4, and 0.3 mm in Figs. 2.5-2.7. 


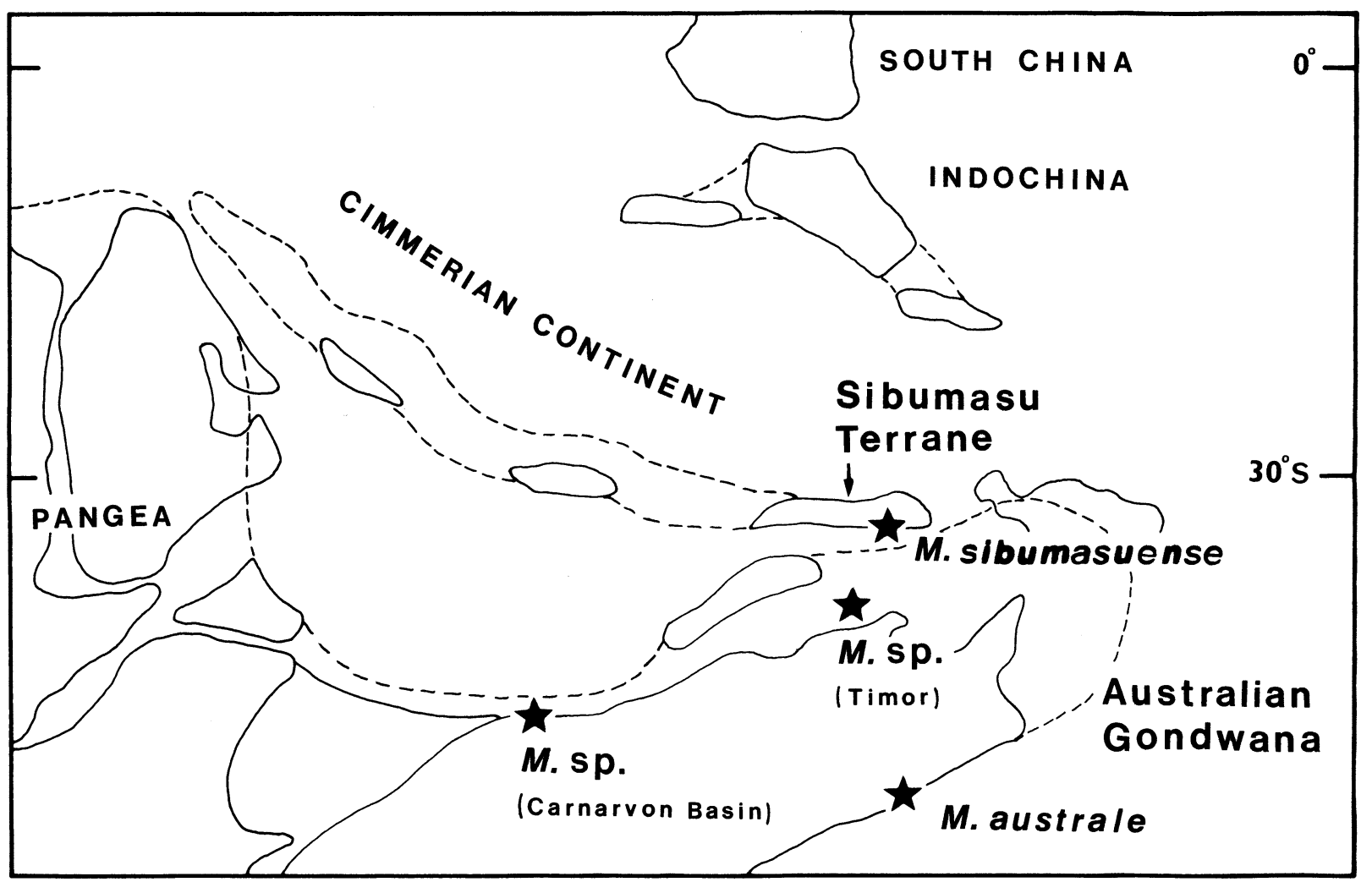

Fig. 3. Palaeogeographic distribution of Mooreoceras in the Australian Gondwana to Sibumasu region. Sakmarian to Roadian species plotted on a late Early Permian palaeogeographic map (base map modified from Metcalfe, $1999^{23)}$ ).

occurs in brownish argillaceous limestone (= Unit 3 of Jones's stratigraphic scheme ${ }^{4)}$ ) that is characteristically accompanied by angular lithoclasts (Fig. 2.7). A ratio of acid insoluble non-carbonate residues attains to 21 in weight \%. Brachiopod shells are dominant in this limestone.

Etymology. The specific name is derived from the Sibumasu Terrane.

Discussion. In the Australian Gondwana region, two Permian forms can be undoubtedly ascribed to Mooreoceras. They are M. sp. from the Sakmarian to Artinskian (middle Lower Permian) Atahoc Formation in East Timor ${ }^{12)}$ and M. australe Waterhouse, $1987^{13)}$ from the Roadian (lower Middle Permian) ${ }^{14)}$ Barfield Formation in the Bowen Basin, eastern Australia. Mooreoceras australe is most similar to M. sibumasuense sp. nov. in shell form and siphuncular position proportions and the absence of cameral and endosiphuncular deposits in the adoral shell. However, the East Australian species differs from the new species by its strongly oblique sutures and thinner $(0.8 \mathrm{~mm})$ shell wall.
The Timorese species has well-developed cameral and endosiphuncular deposits, unlike M. sibumasuense, whose camerae and siphuncle are empty in a nearly corresponding shell size. Teichert $(1951)^{15)}$ reported the occurrence of another $M$. sp. from the upper Sakmarian (middle Lower Permian) Callytharra Formation in the Carnarvon Basin, western Australia. It, however, has never been described or illustrated, hence a comparison with the new species is not possible. Paleogeographic distributions of the above-mentioned four species are given in Fig. 3.

Palaeobiologic implications. The oldest known species of Mooreoceras appeared in the Late Devonian of North America ${ }^{16)}$ and the genus diversified during the Early Carboniferous when it was able to achieve a wide geographic distribution. ${ }^{17), 18)}$ Then its diversity declined, and this decay corresponded with an expansion of cartilaginous fish such as sharks, ${ }^{19)}$ resulting in extinction probably before the Wordian (middle Middle Permian). In Early Permian time, only two isolated refugia of Mooreoceras are recognized, namely the 
Mid-continent region of North America and the Australian Gondwana to Sibumasu region. Only the single species, M. giganteum Clifton, $1942,{ }^{20)}$ is known to occur in the Mid-continent region, and it is probably a relict of the Carboniferous species $M$. normale. Therefore, the present discovery indicates that most Permian species of Mooreoceras are palaeobiogeographically confined to the Australian Gondwana to Sibumasu region. Permian palaeomagnetic ${ }^{21}$ and palaeobiogeographic ${ }^{22)}$ aspects suggest that Australian Gondwana was located in a cool to cool-temperate climate zone. The Sibumasu Terrane separated from Gondwana in the Early Permian, and drifted northwards into the tropical climate zone. ${ }^{23)}$ Oxygen isotope values gained from brachiopod shells in the basal Chuping Formation indicate that the terrane still remained under a cool-temperate water condition in late Kungurian time. ${ }^{24)}$ The group of Mooreoceras in the Australian Gondwana to Sibumasu region probably survived due to isolation from high predatory stress in tropical to temperate seas.

Acknowledgments. We thank Drs. Ian Metcalfe, Tatsuro Matsumoto, M. J. A., and Tamio Nishida for their critical reading of the manuscripts. Sone's $\mathrm{PhD}$ research is supported by scholarships of the IPRS, UNERS and the ASIA Centre. Field work is supported by the Malaysian Government IPPA Project 02-02-020012-EA186IRP.

\section{References}

1) Metcalfe, I. (1984) Mem. Soc. Geol. France [N. S.] 147, 107-118.

2) Sengör, A. M. C. (1979) Nature 279, 590-593.

3) Gobbett, D. J. (1973) In Geology of the Malay Peninsula (West Malaysia and Singapore) (eds. Gobbett, D. J., and Hutchison, C. S.). John Wiley \& Sons, Inc., New York, London, Sydney and Toronto, pp. 61-96.

4) Jones, C. R. (1981) Geol. Surv. Malaysia, District Mem. 17, $1-257$.
5) Ishii, K., Kato, M., Nakamura, K., and Nogami, Y. (1972) J. Geosci., Osaka City Univ. 15, 65-76, pls. 1, 2.

6) Jasin, B., and Koay, L. T. (1990) Sains Malaysiana 19, 35-44.

7) Ueno, K. (2003) Palaeogeogr. Palaeoclimatol. Palaeoecol. 193, 1-24.

8) Agassiz, L. (1847) An Introduction to the Study of Natural History, in a Series of Lectures Delivered in the Hall of the College of Physicians and Surgeons. Greeley \& McElrath, New York.

9) Kuhn, O. (1940) Paläozoologie in Tabellen. Fischer, Jena.

10) Flower, R. H., and Caster, K. E. (1935) Bull. Amer. Paleont. 22, 199-271.

11) Miller, A. K., Dunbar, C. O., and Condra, G. E. (1933) Nebraska Geol. Surv. Bull. 9, 1-240, pls. 1-24.

12) Niko, S., Nishida, T., and Nakazawa, K. (2000) Paleont. Res. 4, 83-88.

13) Waterhouse, J. B. (1987) Palaeontographica Abt. A 198, 129-233, pls. 1-14.

14) Waterhouse, J. B. (2002) Earthwise 4, 1-260.

15) Teichert, C. (1951) Paläont. Zeitschr. 24, 76-90.

16) Flower, R. H. (1939) Palaeontogr. Amer. 2, 1-214, pls. 1-9.

17) Niko, S. (1990) Trans. Proc. Palaeont. Soc. Japan [N. S.], no. 159, 554-561.

18) Histon, K. (1998) Monogr. Palaeontogr. Soc., no. 609, pp. 1-62, pls. 1-7.

19) Colbert, E. H. (1980) Evolution of the Vertebrates, 3rd ed. John Wiley \& Sons, Inc., New York, Chichester, Brisbane and Toronto.

20) Clifton, R. L. (1942) J. Paleont. 16, 685-699, pls. 101-104.

21) Scotese, C. R., and McKerrow, W. S. (1990) In Palaeozoic Palaeogeography and Biogeography (eds. McKerrow, W. S., and Scotese, C. R.). Geol. Soc. London Mem. 12, pp. 1-21.

22) Archbold, N. W. (2000) Mem. Ass. Australasian Palaeont. 23, 287-310.

23) Metcalfe, I. (1999) In Gondwana Dispersion and Asian Accretion (ed. Metcalfe, I.). Balkema, Rotterdam, pp. 9-28.

24) Rao, C. P. (1988) Sediment. Geol. 60, 163-171.

(Received July 14, 2005; accepted Oct. 12, 2005) 